\title{
Transient Early-Life Forebrain Corticotropin-Releasing Hormone Elevation Causes Long-Lasting Anxiogenic and Despair-Like Changes in Mice
}

\author{
Benedict J. Kolber, ${ }^{1,2,3}$ Maureen P. Boyle, ${ }^{1,2,3}$ Lindsay Wieczorek, ${ }^{1,2,3}$ Crystal L. Kelley, ${ }^{1,2}$ Chiamaka C. Onwuzurike, ${ }^{1,2}$ \\ Sabin A. Nettles, ${ }^{4,5}$ Sherri K. Vogt, ${ }^{1,2}$ and Louis J. Muglia ${ }^{4,5}$ \\ Departments of ${ }^{1}$ Pediatrics and ${ }^{2}$ Developmental Biology, and ${ }^{3}$ Neuroscience Program, Washington University, St. Louis, Missouri 63110, and Departments \\ of ${ }^{4}$ Pediatrics and ${ }^{5}$ Molecular Physiology and Biophysics, Vanderbilt University, Nashville, Tennessee 37232
}

\begin{abstract}
During development, early-life stress, such as abuse or trauma, induces long-lasting changes that are linked to adult anxiety and depressive behavior. It has been postulated that altered expression of corticotropin-releasing hormone (CRH) can at least partially account for the various effects of stress on behavior. In accord with this hypothesis, evidence from pharmacological and genetic studies has indicated the capacity of differing levels of CRH activity in different brain areas to produce behavioral changes. Furthermore, stress during early life or adulthood causes an increase in CRH release in a variety of neural sites. To evaluate the temporal and spatial specificity of the effect of early-life CRH exposure on adult behavior, the tetracycline-off system was used to produce mice with forebrain-restricted inducible expression of CRH. After transient elevation of CRH during development only, behavioral testing in adult mice revealed a persistent anxiogenic and despair-like phenotype. These behavioral changes were not associated with alterations in adult circadian or stressinduced corticosterone release but were associated with changes in CRH receptor type 1 expression. Furthermore, the despair-like changes were normalized with antidepressant treatment. Overall, these studies suggest that forebrain-restricted CRH signaling during development can permanently alter stress adaptation leading to increases in maladaptive behavior in adulthood.
\end{abstract}

\section{Introduction}

Early-life stress has important implications for adult health and stress adaptation. Stressful events such as parental loss and physical or emotional abuse can influence or promote the development of mood disorders (for review, see Nemeroff, 2004). These early-life stress experiences are associated with dysregulation of the hypothalamic-pituitary-adrenal (HPA) axis, the endocrine stress response (De Bellis et al., 1994; Lemieux and Coe, 1995; Heim et al., 2000, 2008). Some of the changes in HPA axis activity are detected in adulthood as evidenced by the observation that depressed men who experienced early-life trauma exhibit HPA axis hyperactivity in the corticotropin-releasing hormone (CRH)/ dexamethasone suppression test (Heim et al., 2008). In animal models, maternal deprivation stress induces an increase in anxiety and despair-like behaviors in adulthood (Aisa et al., 2008; Marco et al., 2008), mimicking the observations from humans. The precise mechanism by which early-life stress can influence major depressive disorder (MDD) in adult humans and similar behaviors in rodents is still unclear.

Received Sept. 9, 2009; revised Jan. 4, 2010; accepted Jan. 5, 2010

This work was supported by grants from the National Institutes of Health to B.J.K. (F31MH075250), M.P.B. (F31MH067374), and L.J.M. (AG18876). We thank Maria Elena Morales for manuscript editing.

Correspondence should be addressed to Dr. Louis J. Muglia, Vanderbilt University School of Medicine, 2215 Garland Avenue, MRBIV, Room 1115, Nashville, TN 37232-0007. E-mail: Louis.Muglia@vanderbilt.edu.

M. P. Boyle's present address: Allen Institute for Brain Science, Seattle, WA 02114.

C. L. Kelley's present address: University of Kansas, Wichita, KS 66045.

DOI:10.1523/JNEUROSCI.4470-09.2010

Copyright $\odot 2010$ the authors $\quad 0270-6474 / 10 / 302571-11 \$ 15.00 / 0$
Although many of the long-lasting changes of early-life stress are associated with alterations in hypothalamic function, evidence from animal models has indicated that the limbic forebrain may also play a role in the long-lasting effects of stress (Brunson et al., 2001; Gross et al., 2002). In adult animals and during early postnatal life, psychological stress has been associated with an increase in CRH expression in the rodent hippocampus (Hatalski et al., 2000) and amygdala (Hatalski et al., 1998; Roozendaal et al., 2002). CRH is released at synapses throughout the CNS where it binds to CRH type 1 (CRHR1) and type 2 (CRHR2) receptors. In adults, MDD patients exhibit elevated CRH levels in their CSF following suicide (Arató and Bánki, 1989). Activity of CRH in the amygdala, hippocampus, and cortex has been hypothesized to induce anxiety-like changes related to early-life stress. Forebrain disruption of CRHR1 induces a decrease in anxiety-like behavior revealing the important role that extrahypothalamic CRH plays in the modulation of anxiety (Müller et al., 2003). CRH released during early stress events can bind to CRHR1 at presynaptic and postsynaptic sites (Chen et al., 2004a) to alter growth of hippocampal neurons (Chen et al., 2004b). CRH injected intracerebroventricularly during postnatal development induces memory deficits in adult rats without any observed HPA axis changes (Brunson et al., 2001). These data together with the established role of the limbic system in modulating affective behavior suggest that the forebrain is a potential site of early-life stress modulation of behavior in adulthood.

Present evidence suggests that forebrain CRH is involved in the mechanism by which early-life stress increases anxiety and 
depression in adult animals. To precisely test this hypothesis, we used the tetracycline-off system to overexpress $\mathrm{CRH}$ in the forebrain during development up to postnatal day 21 (P21). We found that early CRH exposure induced lasting anxiogenic and despair-like changes that were reversed with antidepressant treatment. These data suggest that limbic sites of CRH activity play an important role in the long-term effects of early-life stress.

\section{Materials and Methods}

Animals. All mouse protocols were in accordance with National Institutes of Health guidelines and were approved by the Animal Care and Use Committees of Washington University School of Medicine (St. Louis, $\mathrm{MO}$ ) and Vanderbilt University (Nashville, TN). Mice were housed on a $12 \mathrm{~h} / 12 \mathrm{~h}$ light/dark cycle [zeitgeber time (ZT) 0 denotes lights on] with ad libitum access to rodent chow and water. For control of the inducible tetracycline-off system, mice "on doxycycline" were fed doxycycline chow (200 mg doxycycline/1 kg; Research Diets) to repress transgene expression.

To produce forebrain-restricted inducible expression of CRH (FBCRHOE) mice, we constructed a plasmid (pUHCl3-3 backbone vector including the SV40 intron and polyadenylation signal at 3 ' end of the insert) placing the $C R H$ gene [excised with Sall (10 bp upstream of TATA box) and EcoRV (in the $3^{\prime}$ untranslated region)] under control of the tetracycline/doxycycline-responsive cytomegalovirus minimal promoter (tetop-CRH). The promoter and $\mathrm{CRH}$ gene were purified away from vector sequences and microinjected into inbred C57Bl/6 oocytes. The progeny born after pronuclear injection were screened by PCR to identify founder lines harboring the transgene. To generate mice with inducible, forebrain overexpression of $\mathrm{CRH}$, we mated male tetop-CRH mice to female mice expressing the tetracycline transactivator under the control of CaMKII promotor (CaMKII-tTA mice from Jackson Laboratories) (Mayford et al., 1996). Control mice were mice positive for the tetop-CRH transgene or CaMKII-tTA transgene alone or wild-type littermates exposed to doxycycline in the same time frame as their respective overexpressing groups.

Three groups of double transgenic and three groups of control animals, all on an inbred C57 Bl/ 6 background, were used for various studies. $F B C R H O E^{\text {dev }}$ mice were off doxycycline from embryonic day (E) 0 to P21 and so were exposed to CRH transiently during early development. $F B C R H O E^{\text {life }}$ mice were off doxycycline their entire lives and were continuously exposed to CRH overexpression. FBCRHOE doxy mice were on doxycycline their entire lives and were therefore never exposed to $\mathrm{CRH}$ overexpression. Control ${ }^{\mathrm{dev}}$ mice were off doxycycline from E0 to P21 and so were exposed to doxycycline as adults. Control ${ }^{\text {life }}$ mice were off doxycycline their entire lives. Control ${ }^{\text {on doxy }}$ mice were on doxycycline their entire lives. No differences were observed between control dev mice and any of the other control groups (control ${ }^{\text {life }}$ and control ${ }^{\text {on doxy }}$ ) or between control ${ }^{\mathrm{dev}}$ mice and FBCRHOE ${ }^{\text {on doxy }}$ mice. Since no effect of doxycycline was seen in control mice and doxycycline efficiently suppressed overexpression in double transgenic mice, we compared FBCRHOE ${ }^{\mathrm{dev}}$ and control ${ }^{\mathrm{dev}}$ mice in most behavior and CRHR1/GR in situ hybridization experiments to take advantage of within-litter comparisons.

In situ hybridization. For analysis of embryonic CRH overexpression, adult female mice (off doxycycline) were checked for mating plugs at ZT2 ( $2 \mathrm{~h}$ after lights on) following $12 \mathrm{~h}$ of breeding. Embryos were then harvested from plugged females on E12 or E15. Briefly, dams were deeply anesthetized with $2.5 \%$ avertin, and the uterus with embryos was removed into DEPC PBS. Embryos were separated from the uterus, and the placenta and the fetal membranes were removed from each fetus. Embryos were decapitated, placed in 4\% DEPC paraformaldehyde (PFA) overnight, and processed as below.

For postnatal in situ hybridization experiments, male mice 8-12 weeks of age were used. For adult in situ hybridization, brains and pituitary glands were collected at ZT3-6 under nonstressful conditions and processed as previously described (Boyle et al., 2006) to evaluate CRH, glucocorticoid receptor (GR) and CRHR1 mRNA expression in matched sections from FBCRHOE and appropriate control mice. Briefly, mice were deeply anesthetized with $2.5 \%$ avertin and then transcardially perfused with DEPC PBS, followed by $4 \%$ DEPC PFA. Isolated brains were postfixed in $4 \%$ PFA for $24 \mathrm{~h}$, followed by immersion in $10 \%$ sucrose in DEPC PBS. Tissues embedded in OCT (Sakura Finetek USA) were cut into $15 \mu \mathrm{m}$ sections on a cryostat and thaw mounted onto Superfrost Plus slides (Fisher Scientific). An RNA probe complementary to mRNA for CRH (320 bp fragment from PstI to RsaI in exon 2 of CRH gene), GR ( $400 \mathrm{bp}$ fragment targeted to $5^{\prime}$ end of exon 2 of the GR cDNA), or CRHR1 (fragment 25-730 bp from NM_007762) was radiolabeled with $\mathrm{a}^{33} \mathrm{P}$-dUTP, hybridized to sections at an annealing temperature of $60^{\circ} \mathrm{C}$, and washed, after hybridization, in $0.1 \times \mathrm{SSC}$ at $65^{\circ} \mathrm{C}$ for $30 \mathrm{~min}$. Slides were exposed for 1-6 d to Hyperfilm Max (GE Healthcare). Autoradiographic images were scanned at 3200 dots per inch on an Epson 1680 Pro scanner. Densitometric analysis of bilateral limbic (bregma $=-1.32$ $\mathrm{mm}$ ) or pituitary gland in situ signal (two sections per mouse for adult sections and three sections per genotype for developmental E12-P14 sections) was performed using NIH ImageJ software. For adult sections, the in situ signal from two sections per mouse was averaged and normalized with mean control value for each individual anatomical area so that the reported " $n$ " is the number of mice per group, not the number of total sections. For developmental sections, three sections per genotype were normalized with mean control value for each individual anatomical area that was easily identifiable. Control mice sections were a mix of single transgenic and wild-type mice. No negative controls (e.g., sense control) were used for in situ experiments as the signal detected is specific and consistent with that seen previously for these molecules (Muglia et al., 1995; Boyle et al., 2005).

FBCRHOE ${ }^{\mathrm{dev}}$ and control ${ }^{\mathrm{dev}}$ mice were treated with imipramine (16 $\mathrm{mg} / \mathrm{kg}$ in $0.9 \%$ normal saline, $\mathrm{pH} 7.5)$ or vehicle $(0.9 \%$ normal saline, $\mathrm{pH}$ 7.5). Mice were injected intraperitoneally daily (between ZT2 and ZT3) for 3 weeks, killed, and processed as above for CRHR1 mRNA expression $24 \mathrm{~h}$ after their last dose.

CRH immunohistochemistry. Brains were collected under basal conditions. Mice were deeply anesthetized with $2.5 \%$ avertin and then transcardially perfused with PBS, followed by $4 \%$ PFA. Isolated brains were postfixed in $4 \%$ PFA for $24 \mathrm{~h}$, followed by immersion in $10 \%$ sucrose in PBS. Tissues embedded in OCT were cut into $30 \mu \mathrm{m}$ sections on a cryostat and stored in $0.1 \mathrm{M} \mathrm{NaAzide} / \mathrm{PBS}$ at $4^{\circ} \mathrm{C}$ until use. Nonspecific binding for CRH was blocked with 3\% NGS in PBS. Sections were incubated with CRH primary antibody (1:500, Peninsula Laboratories, RGG-8561 rabbit anti-CRH) overnight at $4^{\circ} \mathrm{C}$, washed with PBS, incubated with secondary antibody for $60 \mathrm{~min}$ at room temperature (1:250 biotinylated goat anti-rabbit IgG), incubated in avidin/biotin complex reagent for 60 min, washed with Tris saline, and incubated in a DAB reagent. As a negative control, a section was stained with no primary antibody. In this section, no signal was detected (data not shown). Similar results were seen with the RC-12 CRH antibody (Muglia et al., 1995).

Behavioral analysis. All behavioral analyses were performed by an observer blinded to genotype and treatment. Behavioral tests were done in the morning (ZT3-6). For behavioral analysis, adult male mice 8-16 weeks of age were used. As no differences were observed in pilot studies or in the present studies between single transgenic or wild-type mice, we grouped these mice into a single "control" cohort for each experiment.

Open field. Our open-field apparatus consisted of a Plexiglas box $(76 \times$ $76 \times 30 \mathrm{~cm}$ ). Each mouse was placed in a corner of the open field under low light conditions. Lighting consisted of a single $100 \mathrm{~W}$ incandescent light bulb placed in the corner of the testing room $2.5 \mathrm{~m}$ from the testing arena. Each trial lasted for 10 min with one trial per mouse. Between sessions, the maze was rinsed with $70 \%$ ethanol and dried with paper towels. Latency to enter the center square $(31 \times 31 \mathrm{~cm})$, time in center square, distance traveled in center square, and total distance traveled in all the areas were analyzed using Any-Maze software (Stoelting).

Light/dark preference. As previously described (Boyle et al., 2006), our light/dark (L:D) preference apparatus consisted of a two-compartment standard shuttle box $(20.3 \times 15.9 \times 21.3 \mathrm{~cm}$; Med Associates $)$ with compartments of equal size and a stainless steel bar floor. The compartments were separated by a $3 \times 4 \mathrm{~cm}$ sliding door built into the separating wall. Light was generated by a $100 \mathrm{~W}$ incandescent light bulb placed 22 
$\mathrm{cm}$ over the floor of the light compartment. In this mildly aversive test, mice were placed in the dark compartment and allowed to acclimate for $1 \mathrm{~min}$. The slide door was then opened, and the latency to enter the light compartment, the total time spent in the light compartment, and the total number of entries into the light compartment were recorded for a 10 min trial.

Rotorod. We used the Ugo Basile Accela Roto-Rod apparatus (model 7650 , Jones and Roberts). Each mouse was tested on a stationary rod, continuously rotating rod $(2.5 \mathrm{rpm})$ and accelerating rotating rod (2.5-14 rpm) with two trials on the continuous and accelerating tests. Time spent on the rod was measured for each animal (maximum time for stationary and continuous was $60 \mathrm{~s}$; maximum time for accelerating rod was $180 \mathrm{~s})$.

Sensory-motor battery. The general sensory-motor capabilities of the mice were evaluated using the walk initiation, ledge, platform, $60^{\circ}$ and $90^{\circ}$ inclined screens, and the inverted screen test (Ho et al., 2000). For the walk initiation test, mice were placed in the middle of a square outlined by white tape $(21 \times 21 \mathrm{~cm})$ on a smooth black surface of a large table top. The time it took each mouse to leave the square (place all four paws outside of the tape) was recorded, with a maximum time of $60 \mathrm{~s}$ allowed. For the ledge test, each mouse was timed for how long it could maintain its balance on a narrow $(0.75 \mathrm{~cm}$ thick) Plexiglas ledge without falling (60 s maximum). In the platform test, each mouse was timed for how long it remained on an elevated ( $47 \mathrm{~cm}$ above the floor) circular platform $(1.0 \mathrm{~cm}$ thick, $3.0 \mathrm{~cm}$ diameter). A maximum score of $60 \mathrm{~s}$ was assigned if the mouse remained on the platform for the duration of that time or if it could climb down, without falling, on a very thin pole that supported the platform. The inclined screen test involved placing mice on an elevated wire mesh grid (16 squares per 10) with an aluminum frame that was $15 \times 52 \mathrm{~cm}$ and inclined to $60^{\circ}$ or $90^{\circ}$. Each mouse was placed in the middle of the screen with its head oriented downward and scored for either how long it remained on the screen or how long it took to climb to the top or bottom of the apparatus. A maximum score of $60 \mathrm{~s}$ was given if an animal did not fall. In the inverted screen, mice were placed on screen at $90^{\circ}$ before the screen was moved into the inverted position. Time spent on the screen was measured (60 s maximum).

Tail suspension test. As previously described (Boyle et al., 2005), the tail suspension apparatus consisted of a cubicle made of $1.2 \mathrm{~cm}$ white Plexiglas with inside dimensions of $33 \times 33 \times 32 \mathrm{~cm}$. Mice were suspended by the distal end of their tails from the tail hanger with tape. Activity was scored continuously for immobility behavior across an entire $5 \mathrm{~min}$ trial. Immobility was defined as the lack of all motion except respiration. Graphs were generated by calculating the amount of time each mouse was active.

Forced swim test. As previously described (Boyle et al., 2005), mice were placed in a $2 \mathrm{~L}$ beaker with $1.3 \mathrm{~L}$ of water $\left(18-20^{\circ} \mathrm{C}\right)$. The level of the water prevented the animals from escaping or from reaching the bottom of the container. Mice were continuously monitored for immobility behavior from 1-6 min of a 6 min trial. Immobility was defined as the lack of all motion except respiration and that required to keep the mouse afloat. At the end of the trial, the animal was removed from the water, dried, and returned to its home cage. Graphs were generated by calculating the amount of time each mouse was active during the trial, and the initial latency to float was defined as the first float lasting 3 consecutive seconds.

Antidepressant treatment for behavioral analysis. FBCRHOE ${ }^{\mathrm{dev}}$ and control $^{\mathrm{dev}}$ mice were treated with imipramine $(16 \mathrm{mg} / \mathrm{kg}$ in $0.9 \%$ normal saline, $\mathrm{pH} 7.5)$ or vehicle ( $0.9 \%$ normal saline, $\mathrm{pH}$ 7.5). Mice were injected intraperitoneally daily (between ZT2 and ZT3) for 3 weeks and tested in the tail suspension test (TST) $24 \mathrm{~h}$ after their last dose. Mice were then given an additional $5 \mathrm{~d}$ of imipramine followed by testing in the forced swim test (FST) $24 \mathrm{~h}$ after the last dose. For acute studies, mice were injected with imipramine or vehicle 30 min before testing in the TST or FST. In a separate cohort, mice were injected intraperitoneally daily (between ZT2 and ZT3) for 3 weeks and tested in the open field $24 \mathrm{~h}$ after their last dose.

Radioimmunoassay. Corticosterone and adrenocorticotropic hormone $(\mathrm{ACTH})$ were analyzed by radioimmunoassay as previously described (Boyle et al., 2005).

Circadian analysis. Adult mice were singly or doubly housed at least 1 week before testing [note: housing due to space constraints; no differences were seen within genotypes between single- and double-housed mice, con- sistent with previous literature showing no effect of housing on basal HPA axis activity (Misslin et al., 1982; Holson et al., 1991)]. In adult mice, plasma was collected at circadian nadir (ZT1) and circadian peak (ZT11) by retroorbital phlebotomy. Collection at nadir and peak was done in the same mice separated by 1 week between bleeds. In group-housed juvenile mice, plasma was collected at circadian nadir (ZT1) by rapid decapitation.

Stress analysis. All restraint stress was performed by placing a mouse in a ventilated $50 \mathrm{ml}$ conical tube for $30 \mathrm{~min}$ at ZT1. Plasma was obtained immediately following and $90 \mathrm{~min}$ after the end of the stressor.

Data analysis. Results are expressed as the mean \pm SEM. Student's $t$ test was used to compare pairs of means. In cases of more than two groups, two-way ANOVA was used followed by Bonferroni post hoc tests when appropriate. A one-way ANOVA was used for comparison of the three control groups. A $p$ value $\leq 0.05$ was considered statistically significant. All statistical comparisons were done with Prism 4 software (GraphPad).

\section{Results}

\section{Generation of inducible forebrain-specific $\mathrm{CRH}$} overexpressing mutant mice

To produce an inducible forebrain $\mathrm{CRH}$ overexpressing mouse line, we used the tetracycline-off system, the concept of which has been previously described (Mayford et al., 1996). This system involves two transgenes giving spatial specificity with the CaMKII promoter and reversible repression with the doxycycline-sensitive tetracycline transactivator (tTA). In this system, double transgenic mice given doxycycline should exhibit no transgenic $\mathrm{CRH}$ overexpression. Mice expressing both transgenes (FBCRHOE) have been screened for endogenous CRH expression and forebrain CRH overexpression using in situ hybridization and immunohistochemistry.

\section{Evaluation of CRH expression in FBCRHOE mice on and off doxycycline}

In adult brains, robust CRH mRNA signal was detected throughout the forebrain of lifetime FBCRHOE mice (FBCRHOE ${ }^{\text {life }}$, off doxycycline E0-adult so mice are exposed to transgenic $\mathrm{CRH}$ throughout life). CRH expression was increased in FBCRHOE ${ }^{\text {life }}$ mice in the dorsal hippocampus [Student's $t$ test; dentate gyrus $(\mathrm{DG}): t_{(4)}=6.14, p=0.004$; CA1: $t_{(4)}=7.77, p=0.002$; CA3: $\left.t_{(4)}=11.62, p=0.0003\right]$, caudate/putamen $\left(t_{(4)}=3.07, p=\right.$ $0.04)$, cingulate cortex $\left(t_{(4)}=10.01 p=0.0006\right)$, and somatosensory cortex $\left(t_{(4)}=29.52, p<0.0001\right)$, basolateral nucleus of the amygdala (BLA) $\left(t_{(4)}=3.70, p=0.02\right)$, and central nucleus of the amygdala $(\mathrm{CeA})\left(t_{(4)}=3.52, p=0.02\right)$ compared with control mice (either single transgenic or wild-type mice; control ${ }^{\text {life }}$, off doxycycline E0-adult) but no differences were detected between FBCRHOE ${ }^{\text {life }}$ and control ${ }^{\text {life }}$ mice in the thalamus $\left(_{(4)}=0.04\right.$, $p=0.97$ ) (Fig. $1 A, C$ ). Interestingly, CRH mRNA expression was significantly reduced in the paraventricular nucleus of the hypothalamus $(\mathrm{PVN})\left(t_{(4)}=6.85, p=0.002\right)$ in FBCRHOE ${ }^{\text {life }}$ compared with control life mice (Fig. $1 A, C$ ). To assess whether the $\mathrm{CRH}$ mRNA translated into more $\mathrm{CRH}$ protein, we evaluated expression of $\mathrm{CRH}$ in FBCRHOE ${ }^{\text {life }}$ mice and control ${ }^{\text {life }}$ mice (Fig. $1 E$ ). Focusing on the hippocampus, there is a clear upregulation in $\mathrm{CRH}$ protein in the $F B C R H O E^{\text {life }}$ mice (Fig. $1 E$, inset).

Although the tTA expressing transgene had been previously validated (Mayford et al., 1996), we also verified that CRH overexpression is inhibited in adult FBCRHOE mice that are fed doxycycline chow. We performed in situ hybridization for CRH on adult (>P56) FBCRHOE mice transiently exposed to early $\mathrm{CRH}$ (FBCRHOE ${ }^{\text {dev }}$, off doxycycline E0-P21 so mice are exposed to transgenic $\mathrm{CRH}$ only during early development) and corresponding 
control mice (control ${ }^{\text {dev }}$, off doxycycline E0-P21). No significant differences were seen in CRH mRNA expression between groups in any of the areas quantitated above (DG: $t_{(4)}=1.50, p=0.21$; CA1: $t_{(4)}=1.34, p=0.25$; CA3: $t_{(4)}=1.44$, $p=0.22$; caudate/putamen: $t_{(4)}=0.57$, $p=0.60$; cingulate cortex: $t_{(4)}=0.57, p=$ 0.60 ; somatosensory cortex: $t_{(4)}=0.13$, $p=0.90$; BLA: $t_{(4)}=0.60, p=0.58$; CeA: $t_{(4)}=0.83, p=0.45$; thalamus: $t_{(4)}=0.05$, $p=0.96$; PVN: $t_{(4)}=0.06, p=0.96$ ) (Fig. $1 B, D)$.

To determine the developmental expression of the CRH transgene, we performed in situ hybridization on FBCRHOE ${ }^{\mathrm{dev}}$ and control $^{\text {dev }}$ brains from E12-P14 mice that were off doxycycline (i.e., overexpression on). In young mice, we found a clear upregulation of the $\mathrm{CRH}$ mRNA signal at all time points except in E12 brains (Fig. 2, Table 1). CRH expression was increased in $F B C R H O E^{\mathrm{dev}}$ mice in the amygdala at P1-P14 (Student's $t$ test; P1: $t_{(4)}=5.21$, $p=0.007$; P3: $t_{(4)}=8.37, p=0.001$; P7: $t_{(4)}=9.94, p=0.0006$; P14: $t_{(4)}=3.89$, $p=0.02)$, in the caudate/putamen at E15P14 (E12: $t_{(4)}=0.30, p=0.78 ; \mathrm{E} 15: t_{(4)}=$ 7.91, $p=0.001 ; \mathrm{P} 1: t_{(4)}=7.87, p=0.001$; P3: $t_{(4)}=10.24, p=0.0005 ; \mathrm{P} 7: t_{(4)}=7.29$, $p=0.002$; P14: $\left.t_{(4)}=5.12, p=0.007\right)$, in the frontal cortex at P1-P14 (P1: $t_{(4)}=$ 3.94, $p=0.02 ; \mathrm{P} 3: t_{(4)}=26.49, p<$ 0.0001; P7: $t_{(4)}=5.26, p=0.006$; P14: $\left.t_{(4)}=6.72, p=0.003\right)$, and in the hippocampus at $\mathrm{P} 14$ only $\left(\mathrm{P} 1: t_{(4)}=0.53\right.$, $p=0.63 ; \mathrm{P} 3: t_{(4)}=1.25, p=0.28$; P7: $t_{(4)}=1.73, p=0.16 ;$ P14: $t_{(4)}=2.87, p=$ 0.05 ) compared with control ${ }^{\text {dev }}$ mice (Table 1). There were no significant differences between $F B C R H O E^{\mathrm{dev}}$ and control ${ }^{\mathrm{dev}}$ mice at any time point analyzed in the thalamus (E15: $t_{(4)}=0.58, p=0.59 ; \mathrm{P} 1: t_{(4)}=0.37$, $p=0.73 ; \mathrm{P} 3: t_{(4)}=0.73, p=0.50 ; \mathrm{P} 7: t_{(4)}=0.56, p=0.61 ; \mathrm{P} 14:$ $\left.t_{(4)}=1.56, p=0.19\right)$ or PVN $\left(\mathrm{E} 15: t_{(4)}=0.45, p=0.67\right.$ P $1: t_{(4)}=$ 2.38, $p=0.08$; P3: $t_{(4)}=0.66, p=0.54$; P7: $t_{(4)}=0.88, p=0.43$; P14: $t_{(4)}=1.86, p=0.14$ ) (Table 1). This developmental time frame of transgenic expression is consistent with reports showing activation of the CaMKII promoter during the last 2 weeks of rodent gestation (Burgin et al., 1990) but is different from other reports using the CaMKII promoter in a transgenic manner (Wei et al., 2004; Lu et al., 2008).

\section{Lifetime CRH expression induces a Cushingoid-like phenotype}

As an activator peptide in the HPA axis, CRH overexpression can induce strong activation of the HPA axis leading to pathological levels of glucocorticoids. Previous models of global CRH overexpression exhibited truncal obesity, muscle wasting, hair loss, and thinning of the skin (Stenzel-Poore et al., 1992). To evaluate the possibility of a similar Cushingoid-like phenotype in FBCRHOE mice, we compared lifetime overexpressors $\left(F B C R H O E^{\text {life }}\right)$ and transient overexpressors (FBCRHOE ${ }^{\mathrm{dev}}$ mice) with corresponding control mice for each group of $\mathrm{OE}$ mice. At weaning (i.e., P21), mice from all groups looked outwardly similar. However, by 8 weeks of age FBCRHOE ${ }^{\text {life }}$ mice developed a Cushingoid-like phenotype including truncal obesity, hair loss, and thinning of the skin compared with control ${ }^{\text {life }}$ mice (supplemental Fig. S1 A, available at www.jneurosci.org as supplemental material). Consistent with our in situ data showing suppression of CRH overexpression with doxycycline, FBCRHOE ${ }^{\text {dev }}$ mice showed no Cushingoid-like phenotype at 8 weeks compared with control $^{\text {dev }}$ mice. To quantify the Cushingoid-like phenotype, we compared the adult weights for all groups. FBCRHOE ${ }^{\text {life }}$ mice exhibited reduced weight at adulthood compared with control ${ }^{\text {life }}$ mice (Student's $t$ test; $t_{(32)}=2.52, p=0.02$ ) (supplemental Fig. $S 1 B$, available at www.jneurosci.org as supplemental material). Adult weights of FBCRHOE ${ }^{\mathrm{dev}}$ mice were indistinguishable from control ${ }^{\mathrm{dev}}$ mice $\left(t_{(22)}=0.39, p=\right.$ 0.70 ) (supplemental Fig. $S 1 B$, available at www.jneurosci.org as supplemental material).

\section{Circadian HPA axis activity in mice with lifetime CRH overexpression}

The Cushingoid-like phenotype in FBCRHOE ${ }^{\text {life }}$ mice suggested that these mice may exhibit elevated glucocorticoid levels. To evaluate circadian HPA axis activity, we measured corticosteroid levels at circadian nadir and peak from FBCRHOE ${ }^{\text {life }}$ and con- 


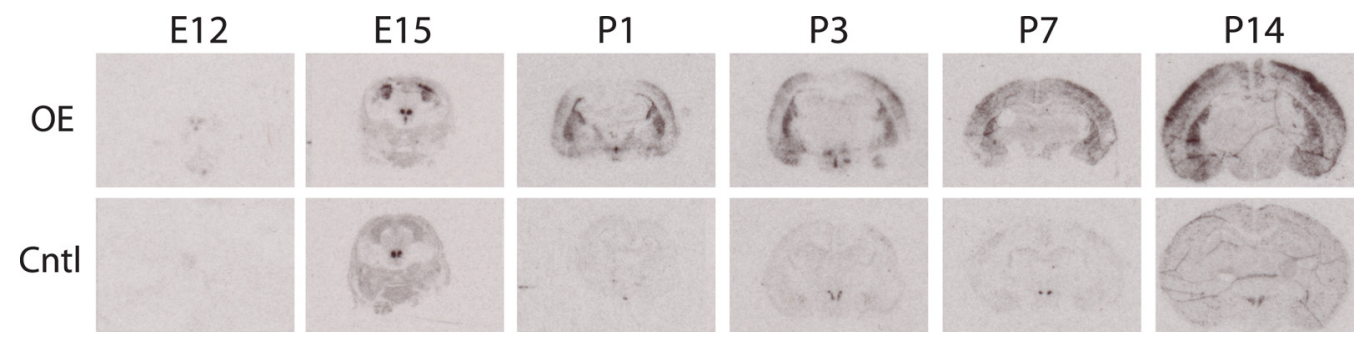

Figure 2. Expression of $C R H$ in $F B C R H O E^{\mathrm{dev}}$ and control ${ }^{\text {dev }}$ mice during development. Representative sections showing CRH mRNA expression from $F B C R H O E^{\text {dev }}(O E)$ and control ${ }^{\text {dev }}(C n t)$ mice at E12, E15, P1, P3, P7 and P14. All mice were off doxycycline when analyzed. Overexpression of CRH likely occurs between E12 and E15.

Table 1. Expression of CRH mRNA during development

\begin{tabular}{|c|c|c|c|c|c|c|}
\hline \multirow[b]{2}{*}{ Developmental age } & \multicolumn{6}{|l|}{ Brain area } \\
\hline & Thalamus & PVN & Amygdala & Caudate/putamen & Frontal cortex & Hippocampus \\
\hline E12 & n.i. & n.i. & n.i. & $0.70 \pm 0.49$ & n.i. & n.i. \\
\hline E15 & $0.79 \pm 0.26$ & $1.58 \pm 0.95$ & n.i. & $12.36 \pm 1.41^{* * *}$ & n.i. & n.i. \\
\hline P1 & $0.90 \pm 0.11$ & $4.98 \pm 2.74$ & $12.46 \pm 2.18^{* *}$ & $25.98 \pm 3.17^{* * *}$ & $10.27 \pm 2.32^{*}$ & $0.35 \pm 1.07$ \\
\hline P3 & $0.68 \pm 0.32$ & $0.74 \pm 0.11$ & $19.00 \pm 2.15^{* * *}$ & $33.86 \pm 3.17^{* * *}$ & $11.64 \pm 0.31^{* * *}$ & $1.67 \pm 0.50$ \\
\hline P7 & $0.74 \pm 0.30$ & $1.55 \pm 0.62$ & $5.37 \pm 0.37^{* * *}$ & $7.11 \pm 0.81^{* *}$ & $3.84 \pm 0.23^{* *}$ & $3.76 \pm 1.54$ \\
\hline P14 & $0.68 \pm 0.16$ & $0.19 \pm 0.07$ & $9.64 \pm 2.20^{*}$ & $11.05 \pm 1.95^{* *}$ & $9.03 \pm 1.13^{* *}$ & $3.36 \pm 0.81^{*}$ \\
\hline
\end{tabular}

Values are reported as mean \pm SEM for FBCRHOE mRNA fold change over control dev signal. Mice were analyzed at E12, E15, P1, P3, P7, and P14. All mice were off doxycycline. Overexpression of CRH likely occurs between E12 and E15. n.i., Not identifiable. ${ }^{*} p \leq 0.05 ;{ }^{* *} p \leq 0.01 ;{ }^{* * *} p \leq 0.001$ compared to control ${ }^{\text {dev; }}$; Student's $t$ test.

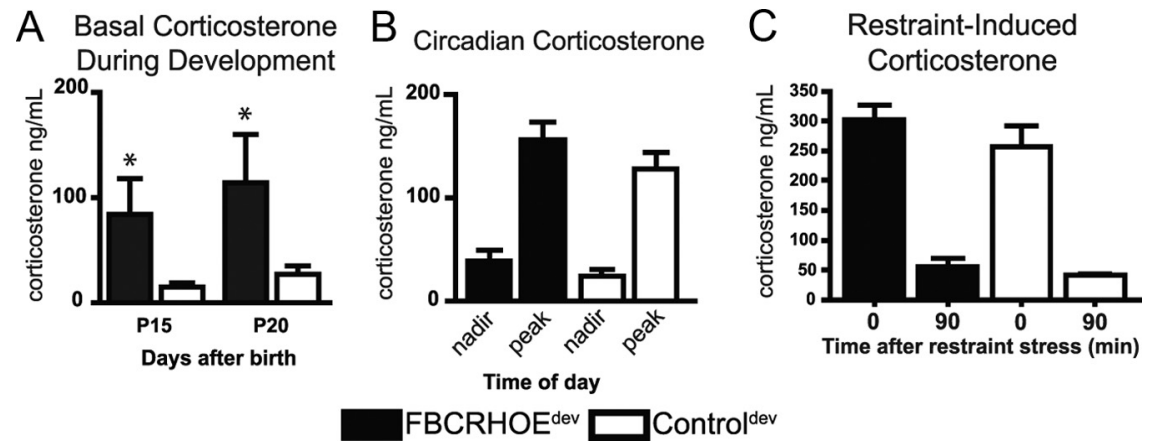

Figure 3. Examination of corticosterone in mice exposed to CRH during development only. $A$, Basal corticosterone is increased in P15 and P20 transient overexpressors (FBCRHOE ${ }^{\text {dev }}$ ) mice $(n=4-5)$ compared with control ${ }^{\text {dev }}$ mice $(n=4-5)$. $\boldsymbol{B}$, No differences are seen between adult $F B C R H O E^{\mathrm{dev}}(n=16)$ and control ${ }^{\mathrm{dev}}$ mice $(n=16)$ in circadian corticosterone. $C$, Adult $F B C R H O E^{\text {dev }}$ mice $(n=9)$ show no alterations in plasma corticosterone 0 or 90 min following restraint stress compared with control ${ }^{\text {dev }}$ mice $(n=9) .0 \mathrm{E}, F B C R H O E^{\text {dev; }}$; $n t l$, control ${ }^{\text {dev }}$. Student's $t$ test; ${ }^{*} p=0.05$ compared with control ${ }^{\text {dev }}$ at specified postnatal day.

trol $^{\text {life }}$ mice. FBCRHOE $E^{\text {life }}$ mice show increased corticosterone (Student's $t$ test; $t_{(16)}=3.63, p=0.002$ ) (supplemental Fig. S1C, available at www.jneurosci.org as supplemental material) and ACTH at circadian nadir (nadir: control ${ }^{\text {life }}, 62.34 \pm 13.77 \mathrm{pg} / \mathrm{ml}$, $n=9 ; F_{B C R H O E}{ }^{\text {life }}, 123.4 \pm 23.40, n=8 ; t_{(15)}=2.311, p=$ 0.04 ), but no differences at circadian peak (corticosterone, $t_{(16)}=$ $0.43, p=0.67$ ) (supplemental Fig. S1C, available at www. jneurosci.org as supplemental material) (ACTH control ${ }^{\text {life }}$, $83.80 \pm 16.98 \mathrm{pg} / \mathrm{ml}, n=8 ;$ FBCRHOE ${ }^{\text {life }}, 63.17 \pm 7.61, n=8$; $\left.t_{(14)}=1.11, p=0.29\right)$.

\section{HPA axis activity in mice with transient early-life CRH overexpression}

A change in the endocrine system is an important component in the hypothesized effects of early-life stress on long-term molecular and behavioral changes. To evaluate the role of HPA axis activity in developmentally exposed FBCRHOE mice, we obtained basal plasma samples from P15 and P20 FBCRHOE ${ }^{\text {dev }}$ mice and control $^{\text {dev }}$ mice. During this early period of transient CRH overexpression (i.e., E15-P21) FBCRHOE ${ }^{\mathrm{dev}}$ mice show elevated cor- ticosterone at P15 (Student's $t$ test; $t_{(6)}=$ $2.00, p=0.05)$ and $\mathrm{P} 20\left(t_{(8)}=1.88, p=\right.$ $0.05)$ compared with control ${ }^{\text {dev }}$ mice (Fig. 3A).

After $\mathrm{CRH}$ overexpression is turned off, comparing adult FBCRHOE ${ }^{\mathrm{dev}}$ and control $^{\text {dev }}$ mice, we found a main effect of time in circadian corticosterone (two-way ANOVA, $\left.F_{(1,59)}=68.7, p<0.0001\right)$ and ACTH levels $\left(F_{(1,56)}=7.03, p=0.01\right)$ but no main effect of genotype or time $X$ genotype for corticosterone (genotype: $F_{(1,59)}=2.59, p=0.11$; time $\times$ genotype: $F_{(1,59)}=0.19, p=0.66$ ) or ACTH (genotype: $F_{(1,56)}=2.98, p=0.09$; time $\times$ genotype: $\left.F_{(1,56)}=0.00, p=0.97\right)$. Bonferroni post hoc tests revealed that adult $F B C R H O E^{\text {dev }}$ overexpressing mice show no significant differences in circadian corticosterone (nadir: $t=0.82, p>0.05$; peak: $t=1.46, p>$ 0.05) (Fig. 3B) or ACTH (nadir: control ${ }^{\mathrm{dev}}, 79.98 \pm 10.29 \mathrm{pg} / \mathrm{ml}$, $n=14 ; F B C R H O E^{\mathrm{dev}}, 107.9 \pm 13.12 \mathrm{pg} / \mathrm{ml}, n=15, t=1.23, p>$ 0.05 ; peak: control ${ }^{\mathrm{dev}}, 122.6 \pm 20.99 \mathrm{pg} / \mathrm{ml}, n=15 ; F B C R H O E^{\mathrm{dev}}$, $149.2 \pm 16.01, n=16, t=1.21, p>0.05){\text { compared with } \text { control }^{\mathrm{dev}}}$ mice.

To investigate the stress-activated HPA axis in adult $F B$ $C R H O E^{\mathrm{dev}}$ mice, we obtained plasma from these mice immediately following and $90 \mathrm{~min}$ after $30 \mathrm{~min}$ of restraint stress. Comparing FBCRHOE ${ }^{\mathrm{dev}}$ to control ${ }^{\mathrm{dev}}$ mice, we found a main effect of time for corticosterone (two-way ANOVA, $F_{(1,18)}=$ $118.9, p<0.0001)$ and $\operatorname{ACTH}\left(F_{(1,35)}=123.0, p<0.0001\right)$ but no main effect for genotype (corticosterone: $F_{(1,18)}=1.56, p=0.22$; ACTH: $\left.F_{(1,35)}=0.12, p=0.74\right)$ or genotype $\times$ time (corticosterone: $F_{(1,18)}=0.5, p=0.49$; ACTH: $\left.F_{(1,35)}=0.41, p=0.53\right)$. Bonferroni post hoc tests revealed that FBCRHOE ${ }^{\mathrm{dev}}$ mice show no differences either immediately following or $90 \mathrm{~min}$ following restraint stress in corticosterone ( 0 min: $t=1.34, p>0.05 ; 90$ min: $t=0.43, p>0.05$ ) (Fig. $3 C$ ) or ACTH (0 min: control ${ }^{\mathrm{dev}}$, 
$368.1 \pm 39.5 \mathrm{pg} / \mathrm{ml} ; \quad F B C R H O E^{\mathrm{dev}}$, $342.4 \pm 29.7 ; t=0.70, p>0.05 ; 90 \mathrm{~min}:$ control $^{\text {dev }}, 59.60 \pm 8.6 \mathrm{pg} / \mathrm{ml} ; \mathrm{FBCRH}-$ $\left.O E^{\mathrm{dev}}, 67.4 \pm 11.5 ; t=0.21, p>0.05\right)$ compared with control ${ }^{\mathrm{dev}}$ mice. Thus, the behavioral changes described below in $F B$ CRHOE ${ }^{\text {dev }}$ mice are not likely due directly to a change in the absolute level of corticosterone seen acutely in the brain during behavioral testing.

\section{Forebrain CRH overexpression results} in altered anxiety-like behavior

As an increase in CRH early in life has been associated with changes in adult behavior, we examined anxiety-like behaviors in mice exposed to early forebrain CRH (FBCRHOE $\left.{ }^{\text {dev }}\right)$ and lifetime overexpressors $\left(F B C R H O E^{\text {life }}\right)$. The open-field test opposes a mouse's innate curiosity to explore a novel area with its aversion to center open spaces. We evaluated the latency to enter the center, total time in the center, number of entries into the center, distance traveled in the center and total distance traveled in the open-field test. Consistent with an increase in anxietylike behavior, FBCRHOE ${ }^{\mathrm{dev}}$ mice show increased latency to enter the center of the field (Student's $t$ test; $t_{(20)}=2.85, p=$ 0.01 ) (Fig. $4 A$ ), reduced time in the center zone $\left(t_{(20)}=2.05, p=0.05\right)$ (Fig. $4 B$ ), reduced number of entries in the center zone $\left(t_{(20)}=2.68, p=0.01\right)$ (Fig. $4 C$ ), and reduced distance traveled in the center $\left(t_{(20)}=2.05, p=0.05\right)$ (Fig. $\left.4 D\right)$ compared with control ${ }^{\mathrm{dev}}$ mice. As a measure of locomotor output, $F B$ $C R H O E^{\mathrm{dev}}$ mice show equivalent distance traveled in the open field $\left(t_{(20)}=1.19, p=0.25\right.$ ) (Fig. $4 E$ ) compared with control ${ }^{\mathrm{dev}}$ mice.

Although our in situ data in FBCRHOE ${ }^{\text {dev }}$ adult mice suggested that doxycycline repressed transgenic CRH expression appropriately, we wanted to test the efficacy of doxycycline further by comparing the behavior of control ${ }^{\mathrm{dev}}$ mice to lifetime nonoverexpressing FBCRHOE mice (FBCRHOE ${ }^{\text {on doxy }}$, on doxycycline $\mathrm{E} 0->\mathrm{P} 56$, so mice were never exposed to transgenic $\mathrm{CRH}$ ). We reasoned that if doxycycline repressed transgenic $\mathrm{CRH}$ in $F B C R H O E^{\text {on doxy }}$ mice, their behavior would be indistinguishable from control ${ }^{\text {dev }}$ mice. Supporting this hypothesis, we found no significant differences between control ${ }^{\mathrm{dev}}$ mice and lifetime non-overexpressing $F B C R H O E^{\text {on doxy }}$ mice in latency to enter the center (control ${ }^{\text {dev }}: 42.42 \pm 8.30 \mathrm{~s}, n=11 ;$ FBCRHOE $^{\text {on doxy }}$ : $46.42 \pm 6.18 \mathrm{~s}, n=6$; Student's $t$ test; $t_{(15)}=0.32, p=0.76$ ), time in center square (control ${ }^{\mathrm{dev}}: 24.37 \pm 3.82 \mathrm{~s}, n=11 ; \mathrm{FBCRHOE}^{\text {on doxy. }}$ : $\left.24.70 \pm 1.41 \mathrm{~s}, n=6 ; t_{(15)}=0.06, p=0.95\right)$, entries into the center (control ${ }^{\text {dev }}: 15.55 \pm 1.77$ entries, $n=11 ;$ FBCRHOE $^{\text {on doxy }}: 15.33 \pm$ 2.22 entries, $\left.n=6 ; t_{(15)}=0.07, p=0.94\right)$, distance in center square (control ${ }^{\text {dev }}: 3.34 \pm 0.33 \mathrm{~m}, n=11$; FBCRHOE ${ }^{\text {on doxy }}: 3.26 \pm$ $\left.0.52 \mathrm{~m}, n=6 ; t_{(15)}=0.21, p=0.83\right)$, or total distance traveled (control ${ }^{\mathrm{dev}}: 62.40 \pm 3.90 \mathrm{~m}, n=11 ;$ FBCRHOE $^{\text {on doxy }}: 59.08 \pm$ $\left.10.12 \mathrm{~m}, n=6 ; t_{(15)}=0.37, p=0.72\right)$.

One potential caveat of the tetracycline-off system is that doxycycline treatment could induce behavioral changes independent of genotype. To evaluate possible nonspecific effects of doxycycline treatment, we compared control ${ }^{\mathrm{dev}}$ mice (on doxy P21-adult), control $^{\text {on doxy }}$ mice (on doxy E0-adult) and control ${ }^{\text {life }}$ mice (off doxy E0-adult). In open-field testing, using a one-way ANOVA we found no significant differences between control $^{\text {dev }}$ mice, control ${ }^{\text {on doxy }}$ mice and control ${ }^{\text {life }}$ mice in latency to enter the center (control ${ }^{\text {dev }}$ : $42.42 \pm 8.30 \mathrm{~s}, n=11$; control $^{\text {on doxy }}: 66.38 \pm 20.12, n=6$; control $\left.^{\text {life }}: 47.56 \pm 15.3, n=9 ; F_{(2,23)}=0.66, p=0.53\right)$, time in center square (control ${ }^{\text {dev }}$ : $24.37 \pm 3.82 \mathrm{~s}, n=11$; control $^{\text {on doxy }}$ : $17.02 \pm 3.70, n=6$; control $^{\text {life }}: 18.33 \pm 2.69, n=9 ; F_{(2,23)}=1.22$, $p=0.31$ ), entries into the center (control ${ }^{\mathrm{dev}}: 15.55 \pm 1.77$ entries, $n=11$; control $^{\text {on doxy }}: 17.0 \pm 3.18, n=6$; control $^{\text {life }}: 17.25 \pm 1.9$, $\left.n=9 ; F_{(2,23)}=0.20, p=0.82\right)$, distance in center square (control ${ }^{\mathrm{dev}}$ : $3.34 \pm 0.33 \mathrm{~m}, n=11$; control $^{\text {on doxy }}: 3.60 \pm 0.67, n=6$; control $^{\text {life }}$ : $\left.3.71 \pm 0.55, n=9 ; F_{(2,23)}=0.13 p=0.88\right)$, or total distance traveled (control ${ }^{\mathrm{dev}}: 62.40 \pm 3.90 \mathrm{~m}, n=11$; control $^{\text {on doxy }}: 56.04 \pm 5.02$, $n=6$; control $\left.{ }^{\text {life }}: 66.40 \pm 5.07, n=9 ; F_{(2,23)}=1.06, p=0.36\right)$.

We next analyzed anxiety and locomotor behavior in FBCRHOE $E^{\text {life }}$ mice using the open-field test. Similar to FBCRHOE ${ }^{\mathrm{dev}}$ mice, FBCRHOE ${ }^{\text {life }}$ mice show increased latency to enter the center of the field (control life, $47.56 \pm 15.34 \mathrm{~s}$; FBCRHOE ${ }^{\text {life }}, 177.5 \pm 49.58 \mathrm{~s}$; Student's $t$ test; $t_{(16)}=2.50, p=$ 0.02 ), a trend toward reduced time in the center zone (control ${ }^{\text {life, }}$, $18.33 \pm 2.69 \mathrm{~s} ;$ FBCRHOE ${ }^{\text {life }}, 11.94 \pm 2.31 \mathrm{~s} ; t_{(16)}=1.80, p=$ 0.09 ), reduced number of entries in the center zone (control life, $15.89 \pm 2.18$ entries; FBCRHOE ${ }^{\text {life }}, 9.00 \pm 2.30$ entries; $t_{(16)}=$ $2.18, p=0.04$ ), and reduced distance traveled in the center (control $^{\text {life }}, 3.71 \pm 0.56 \mathrm{~m} ; F B C R H O E^{\text {life }}, 1.95 \pm 0.56 \mathrm{~m} ; t_{(16)}=2.21$, $p=0.04)$ compared with control ${ }^{\text {life }}$ mice. However, confounding these anxiety-like measures, FBCRHOE ${ }^{\text {life }}$ mice showed decreased distance traveled in the open field compared with control ${ }^{\text {life }}$ mice 


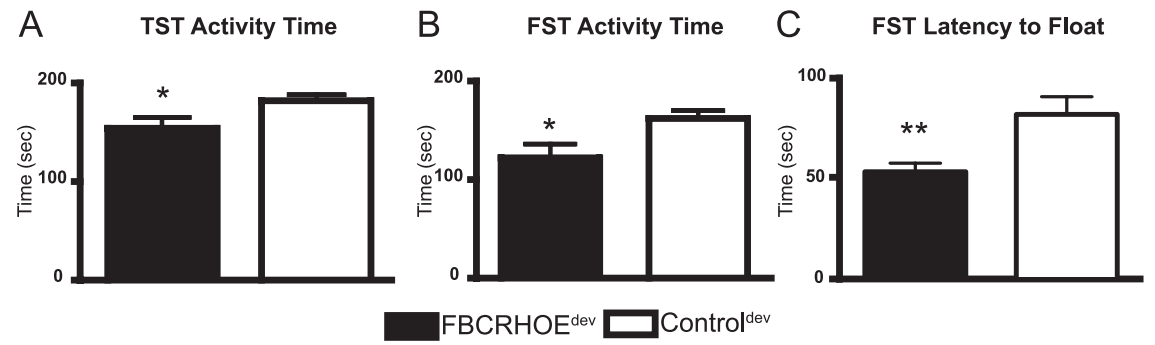

Figure 5. $F B C R H O E^{\mathrm{dev}}$ mice exhibit despair-like behavior in the TST and FST. $\boldsymbol{A}$, In the TST, FBCRHOE ${ }^{\mathrm{dev}}$ mice $(n=12)$ show reduced activity compared with control ${ }^{\text {dev }}$ mice $(n=12) . \boldsymbol{B}, \boldsymbol{C}$, In the FST, $F B C R H O E^{\text {dev }}$ mice $(n=9)$ show reduced activity $(\boldsymbol{B})$ and reduced latency to float $(\boldsymbol{C})$ compared with control ${ }^{\text {dev }}$ mice $(n=11)$. Student's $t$ test; ${ }^{*} p \leq 0.05 ;{ }^{* *} p=0.01$ compared with control $^{\text {dev }}$ mice.

(control $^{\text {life }}, 66.52 \pm 5.07 \mathrm{~m} ;$ FBCRHOE $E^{\text {life }}, 44.51 \pm 4.89 \mathrm{~m} ; t_{(16)}=$ $3.12, p=0.007)$. Due to this locomotor change, the Cushingoid-like phenotype of $F B C R H O E^{\text {life }}$ mice and the established data on other models of lifetime CRH overexpression (Stenzel-Poore et al., 1992, 1994), we did not test these mice in any other anxiety or despair-like behavioral tests.

To validate the anxiogenic phenotype of FBCRHOE ${ }^{\mathrm{dev}}$ mice in open-field testing, we tested mice exposed to $\mathrm{CRH}$ during development in L:D preference. L:D preference is a common test for anxiety-like behavior that pits an animal's instinct for exploration against the animal's aversion to bright spaces. In L:D preference, mice start in a dark chamber and are allowed to cross over to a light chamber. The latency to enter the light chamber and time spent in the chamber are measures of anxiety-like behavior. $F B C R H O E^{\mathrm{dev}}$ mice show increased latency to enter the light compartment (Student's $t$ test; $t_{(20)}=2.41, p=0.03$ ) (Fig. $\left.4 F\right)$, decreased number of entries into the light $\left(t_{(20)}=2.77, p=0.01\right)$ (Fig. $4 G$ ) and reduced total time spent in the light compartment compared with control ${ }^{\mathrm{dev}}$ mice $\left(t_{(20)}=2.21, p=0.04\right)($ Fig. $4 H)$. We found no significant differences between control ${ }^{\text {dev }}$ mice and $F B C R H O E^{\text {on doxy }}$ in latency to enter the light (control ${ }^{\text {dev }}: 6.45 \pm$ $1.30 \mathrm{~s}, n=11$; FBCRHOE ${ }^{\text {on doxy }}: 5.83 \pm 0.87 \mathrm{~s}, n=6$; Student's $t$ test; $\left.t_{(15)}=0.33, p=0.75\right)$, number of entries into the light (control $^{\text {dev }}: 22.36 \pm 1.61$ entries, $n=11$; FBCRHOE ${ }^{\text {on doxy. }}$ : $22.83 \pm 1.33$ entries, $\left.n=6 ; t_{(15)}=0.19, p=0.84\right)$, or total time spent in the light (control ${ }^{\text {dev }}$ : $329.9 \pm 16.23 \mathrm{~s}, n=11$; FBCRHOE $\left.^{\text {on doxy }}: 340.5 \pm 8.44 \mathrm{~s}, n=6 ; t_{(15)}=0.45, p=0.65\right)$. In L:D preference, using a one-way ANOVA, we found no significant differences between control ${ }^{\text {dev }}$ mice, control $^{\text {on doxy }}$ mice and control ${ }^{\text {life }}$ mice in latency to enter the light $\left(\right.$ control $^{\text {dev }}: 6.45 \pm 1.30 \mathrm{~s}$, $n=11$ control $^{\text {on doxy }}: 6.50 \pm 1.15 \mathrm{~s}, n=6$; control ${ }^{\text {life }}: 4.78 \pm 1.61 \mathrm{~s}$, $\left.n=9 ; F_{(2,23)}=0.41, p=0.67\right)$, number of entries into the light (control ${ }^{\text {dev }}: 22.36 \pm 1.61$ entries, $n=11$; control $^{\text {on doxy }}: 24.33 \pm$ 1.12 entries, $n=6$; control ${ }^{\text {life }}: 25.78 \pm 2.62$ entries, $n=9 ; F_{(2,23)}=$ $0.87, p=0.43$ ), or total time spent in the light (control ${ }^{\mathrm{dev}}: 329.9 \pm$ $16.23 \mathrm{~s}, n=11$; control $^{\text {on doxy }}: 322.0 \pm 11.97 \mathrm{~s}, n=6$; control $^{\text {life: }}$ : $\left.307.4 \pm 25.53 \mathrm{~s}, n=9 ; F_{(2,23)}=0.98, p=0.39\right)$.

Although our behavioral testing indicated an increase in anxiogenic behavior in FBCRHOE ${ }^{\mathrm{dev}}$ mice, it also revealed a possible motoric change in L:D preference with $F B C R H O E^{\mathrm{dev}}$ mice showing decreased number of light entries. To determine the significance of any motoric deficit, we tested $F B C R H O E^{\mathrm{dev}}$ in the rotorod test and a sensory-motor battery. In all tests, $F B C R H O E^{\mathrm{dev}}$ mice failed to show any statistically significant differences compared with control ${ }^{\text {dev }}$ mice (supplemental Fig. S2, available at www.jneurosci.org as supplemental material).
Forebrain CRH overexpression results in increased depression-like behavior MDD is associated with a variety of changes in behavior including loss of energy, sleep alterations, learning and memory impairments, anhedonia, and helplessness (despair). To evaluate the role of CRH in despair-like behavior, we tested FBCRHOE ${ }^{\text {dev }}$ mice in the TST and FST. In both tests, reduced activity is associated with an increase in despair-like behavior as a variety of antidepressants increase activity in these tests in mice and rats. In the TST, $F B C R H O E^{\mathrm{dev}}$ mice show reduced activity (increase in despair-like behavior) compared with control ${ }^{\text {dev }}$ mice $\left(t_{(22)}=2.12\right.$, $p=0.05$ ) (Fig. 5A). Consistent with their depression-like phenotype in the TST, FBCRHOE ${ }^{\text {dev }}$ mice show reduced activity in the FST compared with control $^{\mathrm{dev}}$ mice $\left(t_{(18)}=2.52, p=0.02\right)$ (Fig. $\left.5 B\right)$. Furthermore, $F B C R H O E^{\text {dev }}$ mice exhibit decreased latency to float in the FST compared with control ${ }^{\mathrm{dev}}$ mice $\left(t_{(18)}=3.07, p=0.01\right)$ (Fig. 5C). We found no significant differences between control ${ }^{\text {dev }}$ mice and lifetime non-overexpressing FBCRHOE ${ }^{\text {on doxy }}$ mice in TST activity (control ${ }^{\text {dev }}: 181.30 \pm 6.69 \mathrm{~s}, n=12 ;$ FBCRHOE $^{\text {on }}$ ${ }^{\text {doxy }}: 195.8 \pm 8.55 \mathrm{~s}, n=6$; Student's $t$ test; $t_{(16)}=1.29, p=0.21$ ), FST activity (control ${ }^{\mathrm{dev}}: 161.2 \pm 8.24 \mathrm{~s}, n=11 ; \mathrm{FBCRHOE}^{\mathrm{on}}$

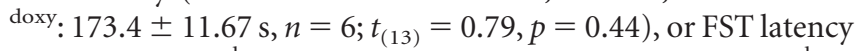
to float (control ${ }^{\text {dev }}: 78.19 \pm 10.05 \mathrm{~s}, n=11$; FBCRHOE ${ }^{\text {on doxy }}$ : $\left.112.5 \pm 20.96 \mathrm{~s}, n=6 ; t_{(13)}=1.67, p=0.12\right)$. Using a one-way ANOVA we found no significant differences between control ${ }^{\text {dev }}$ mice, control ${ }^{\text {on doxy }}$ mice and control ${ }^{\text {life }}$ mice in TST activity (control ${ }^{\text {dev }}: 181.30 \pm 6.69 \mathrm{~s}, n=12$; control $^{\text {on doxy }}: 210.9 \pm 17.88$ s, $n=6$; control life: $183.2 \pm 13.50 \mathrm{~s}, n=8$; Student's $t$ test; $\left.F_{(2,23)}=1.73, p=0.20\right)$. In the FST, using Student's $t$ test we found no difference between control ${ }^{\mathrm{dev}}$ mice and control $^{\text {on doxy }}$ mice in FST activity (control ${ }^{\mathrm{dev}}: 161.2 \pm 8.24 \mathrm{~s}, n=11$; control $^{\text {on doxy }}$, $\left.160.9 \pm 10.60 \mathrm{~s}, n=5 ; t_{(14)}=002, p=0.99\right)$ or FST latency to float (control $^{\text {dev }}: 78.19 \pm 10.05 \mathrm{~s}, n=11$; control ${ }^{\text {on doxy }}: 102.0 \pm 9.70$, $n=5 ; t_{(14)}=1.44, p=0.17$ ) (note: control ${ }^{\text {life }}$ mice were never tested in FST).

Treatment with the tricyclic antidepressant imipramine reverses depression-like behavior in FBCRHOE mice

To determine the effect of antidepressant activity on behavioral deficits in FBCRHOE mice exposed to CRH early in life, we treated $F B C R H O E^{\mathrm{dev}}$ and control ${ }^{\mathrm{dev}}$ mice with the tricyclic antidepressant, imipramine, or vehicle, chronically. We treated $F B C R H O E^{\mathrm{dev}}$ and control ${ }^{\mathrm{dev}}$ mice with daily imipramine or saline for 3-4 weeks before performing TST and FST. In the TST, we found a significant interaction of genotype $\times$ treatment but no main effect of treatment or genotype (two-way ANOVA genotype $\times$ treatment: $F_{(1,20)}=5.99, p=0.02$; treatment: $F_{(1,20)}=$ $0.82, p=0.38$; genotype: $\left.F_{(1,20)}=3.77, p=0.07\right)$. Bonferroni post hoc tests revealed a significant difference between $F B C R H O E^{\mathrm{dev}}$ saline-treated mice and saline-treated control ${ }^{\mathrm{dev}}$ mice $(t=3.10$, $p<0.05$ ) (Fig. 6A). Similarly, in the FST, we found a significant interaction of genotype $\times$ treatment but no main effect of treatment or genotype (genotype $\times$ treatment: $F_{(1,19)}=8.13, p=$ 0.01 ; treatment: $F_{(1,19)}=2.89, p=0.11$; genotype: $F_{(1,19)}=1.40$, $p=0.25)$. Bonferroni post hoc tests revealed a significant difference between $F B C R H O E^{\text {dev }}$ saline-treated mice and saline-treated control $^{\mathrm{dev}}$ mice in the FST $(t=2.79, p<0.05)$ (Fig. 6B). However, imipramine normalized the activity level in FBCRHOE ${ }^{\mathrm{dev}}$ mice in 


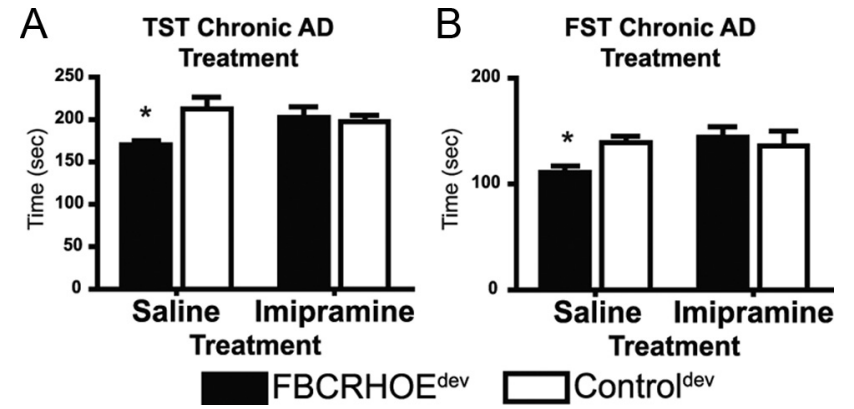

Figure 6. Effects of chronicimipramine [antidepressant (AD)] on $F B C R H O E^{\text {dev }}$ despair-like behavior. $A, F B C R H O E^{\text {dev }}$ mice $(n=6)$ treated with chronic imipramine show no difference in TST activity compared with control ${ }^{\text {dev }}$ mice $(n=6)$ treated with imipramine. $B, F B C R H O E^{\mathrm{dev}}$ mice $(n=6)$ treated with chronic imipramine show no difference in FST activity compared with control $^{\text {dev }}$ mice $(n=6)$ treated with imipramine. Saline (vehicle)-treated $F B C R H O E^{\text {dev }}$ continued to show despair-like behavior compared with control ${ }^{\text {dev }}$ saline-treated mice in the TST $(\boldsymbol{A})$ and FST (B). Bonferroni test; ${ }^{*} p<0.05$ versus saline-treated control dev.

both the TST $(t=0.36, p>0.05)$ (Fig. $6 A)$ and FST $(t=1.21, p>$ 0.05 ) (Fig. $6 B$ ) compared with imipramine-treated control ${ }^{\mathrm{dev}}$ mice. Using an acute treatment schedule, we found similar results in both the TST and FST compared with those reported above for chronic treatment with imipramine (supplemental Fig. S3 $A, B$, available at www.jneurosci.org as supplemental material). In slight contrast, in the acute FST, imipramine caused a significant increase in activity in both control ${ }^{\mathrm{dev}}$ and FBCRHOE ${ }^{\mathrm{dev}}$ mice (supplemental Fig. S3B, available at www.jneurosci.org as supplemental material).

The reversal of despair-like behavior after imipramine treatment suggests a specific mode of action regarding the pharmacological effects of imipramine on despair. However, it is possible that imipramine is nonspecifically increasing locomotor behavior causing an apparent normalization of the despair-like behavior. To address this question and to determine the effect of imipramine on anxiety-like behavior, we treated $F B C R H O E^{\text {dev }}$ and control ${ }^{\mathrm{dev}}$ mice with imipramine, or vehicle, chronically and then tested the mice in the open field (supplemental Fig. S3C-G, available at www.jneurosci.org as supplemental material). We found no evidence for an effect of imipramine on total distance traveled (two-way ANOVA main effect, treatment $\times$ genotype: $F_{(1,12)}=0.68, p=0.43$; treatment: $F_{(1,12)}=0.14, p=0.71$; genotype: $F_{(1,12)}=0.49, p=0.50$ ) (supplemental Fig. $S 3 G$, available at www.jneurosci.org as supplemental material) suggesting that our previous results in despair-like behavior were not confounded by a nonspecific increase in locomotor output with imipramine treatment. Surprisingly, testing the ability of imipramine to normalize anxiety-like behavior in FBCRHOE ${ }^{\mathrm{dev}}$ mice, we found no main effects of treatment $\times$ genotype, treatment or genotype for latency to enter the center (treatment $\times$ genotype: $F_{(1,12)}=0.04, p=0.84$; treatment: $F_{(1,12)}=0.39, p=0.56$; genotype: $F_{(1,12)}=0.01, p=0.93$ ) (supplemental Fig. S3C, available at www.jneurosci.org as supplemental material), time in the center (treatment $\times$ genotype: $F_{(1,12)}=0.14, p=0.71$; treatment: $F_{(1,12)}=0.01, p=0.99$; genotype: $\left.F_{(1,12)}=1.43, p=0.25\right)$ (supplemental Fig. S3D, available at www.jneurosci.org as supplemental material), or distance traveled in the center (treatment $\times$ genotype: $F_{(1,12)}=0.19, p=0.67$; treatment: $F_{(1,12)}=0.03, p=0.88$; genotype: $F_{(1,12)}=1.74, p=0.21$ ) (supplemental Fig. S3F, available at www.jneurosci.org as supplemental material). We found a significant main effect of genotype and treatment for the number of entries into the center (treatment $\times$ genotype: $F_{(1,12)}=1.19, p=$ 0.30 ; treatment: $F_{(1,12)}=6.00, p=0.03$; genotype: $F_{(1,12)}=9.78$, $p=0.01$ ) (supplemental Fig. S3E, available at www.jneurosci.org as supplemental material). Bonferroni post hoc tests revealed that FBCRHOE ${ }^{\mathrm{dev}}$ saline-treated mice make fewer entries into the center compared with control ${ }^{\mathrm{dev}}$ saline-treated mice $(t=2.98$, $p<0.05)$ but that FBCRHOE ${ }^{\mathrm{dev}}$ mice treated with imipramine make equivalent number of entries into the center compared with imipramine-treated control ${ }^{\mathrm{dev}}$ mice $(t=1.44, p>0.05)$. Overall, these data suggest that daily injections (of imipramine or saline) have no effect on total locomotor output but may have a nonspecific effect on anxiety that masks many of the basal differences between genotypes.

\section{Analysis of GR and CRHR1 expression after early exposure to $\mathrm{CRH}$}

To investigate the mechanism of the behavioral deficits in FBCRHOE ${ }^{\mathrm{dev}}$ mice, we evaluated GR and CRHR1 mRNA expression in adult developmental animals. Both of these molecules are related to the effects of early-life stress and both have the capacity to be regulated by $\mathrm{CRH}$ and corticosterone signaling. We evaluated GR mRNA expression by in situ hybridization in the PVN, CeA, BLA, DG and CA1. FBCRHOE ${ }^{\text {dev }}$ mice show no significant changes in GR mRNA compared with control ${ }^{\text {dev }}$ mice in the PVN (Student's $t$ test; $\left.t_{(16)}=0.20, p=0.85\right)$, CeA $\left(t_{(16)}=0.69, p=\right.$ $0.50)$, BLA $\left(t_{(16)}=0.50, p=0.63\right)$, or DG $\left(t_{(16)}=0.35, p=0.74\right)$ although we observed a trend toward increased CA1 GR mRNA in FBCRHOE ${ }^{\mathrm{dev}}$ mice $\left(t_{(16)}=1.92, p=0.07\right)$ (Fig. $7 A$ ). We also evaluated CRHR1 mRNA expression by in situ hybridization in the BLA, cingulate cortex, DG, CA1, CA3, and the pituitary gland. In contrast to the GR results, FBCRHOE ${ }^{\text {dev }}$ mice expressed increased CRHR1 mRNA in the cingulate cortex $\left(t_{(16)}=2.82\right.$, $p=0.01), \mathrm{DG}\left(t_{(16)}=2.44, p=0.03\right)$, and CA1 $\left(t_{(16)}=2.27, p=\right.$ $0.04)$ with equivalent CRHR1 in the $\operatorname{BLA}\left(t_{(16)}=1.34, p=0.20\right)$, area CA3 $\left(t_{(16)}=1.61, p=0.13\right)$, and the pituitary gland $\left(t_{(5)}=\right.$ $1.58, p=0.17$ ) compared with control ${ }^{\mathrm{dev}}$ mice (Fig. $7 B$ ). Observing this basal CRHR1 change and the behavioral normalization of TST and FST with imipramine, we wanted to assess whether imipramine treatment influences CRHR1 expression in either the FBCRHOE ${ }^{\text {dev }}$ or control ${ }^{\text {dev }}$ mice. After chronic treatment with imipramine, we found a significant reduction in CRHR1 signal comparing saline-treated $F B C R H O E^{\mathrm{dev}}$ and imipramine-treated FBCRHOE ${ }^{\mathrm{dev}}$ mice in the cingulate cortex $\left(t_{(6)}=3.54, p=0.01\right)$ and CA1 $\left(t_{(6)}=2.80, p=0.03\right)$ (Fig. $\left.7 C\right)$. In contrast, we found no significant difference between saline and imipramine-treated control ${ }^{\mathrm{dev}}$ mice in the cingulate cortex $\left(t_{(6)}=0.42, p=0.69\right)$ or CA1 $\left(t_{(6)}=0.81, p=0.45\right)$ in CRHR1 mRNA expression. No differences were seen within genotypes between saline and imipramine treatment for the BLA, DG or CA3 (data not shown).

\section{Discussion}

Although multiple lines of evidence have suggested that $\mathrm{CRH}$ is an important component in the pathogenesis of MDD, the spatial specificity of $\mathrm{CRH}$ action and the role of $\mathrm{CRH}$ in mediating the effects of early-life stress remain unresolved. Here, we report that elevation of $\mathrm{CRH}$ during early development induces long-lasting changes in adult anxiety in L:D preference and open-field behavior and despairlike activity in the TST and FST. Furthermore, the behavioral changes were accompanied by changes in CRHR1 expression. Finally, our observations that the despair-like behavioral deficits were normalized with imipramine treatment has important implications for understanding the role of an altered stress adaptation system in the treatment of MDD associated with early-life abuse.

The tetracycline-off system described here is a useful model to investigate the role of $\mathrm{CRH}$ and the HPA axis in modulating the 
A $\quad$ GR mRNA (basal conditions)
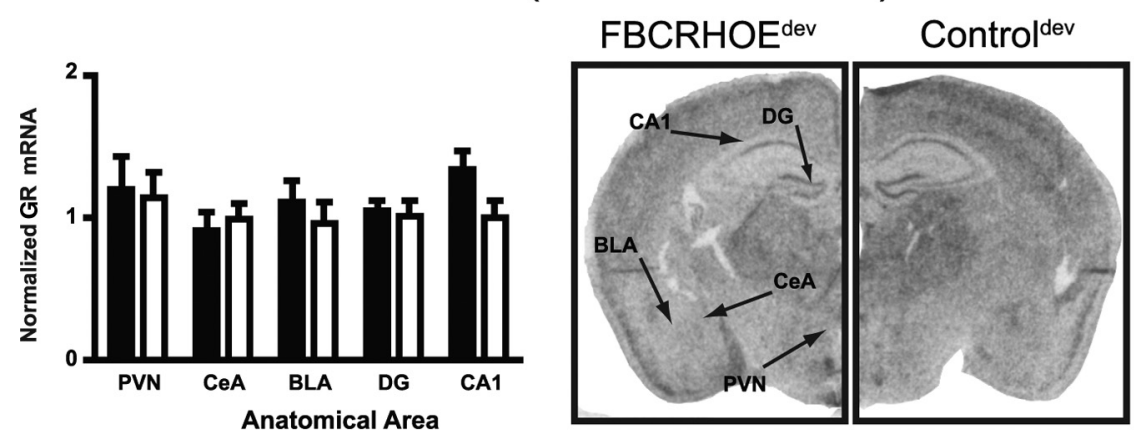

B

CRHR1 mRNA (basal conditions)

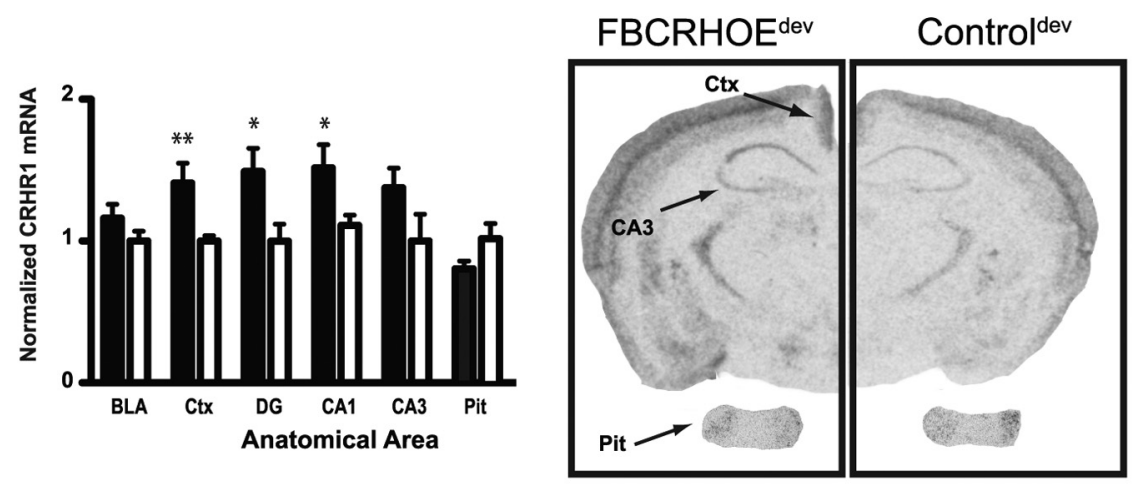

C $\quad$ CRHR1 mRNA (imipramine treatment)
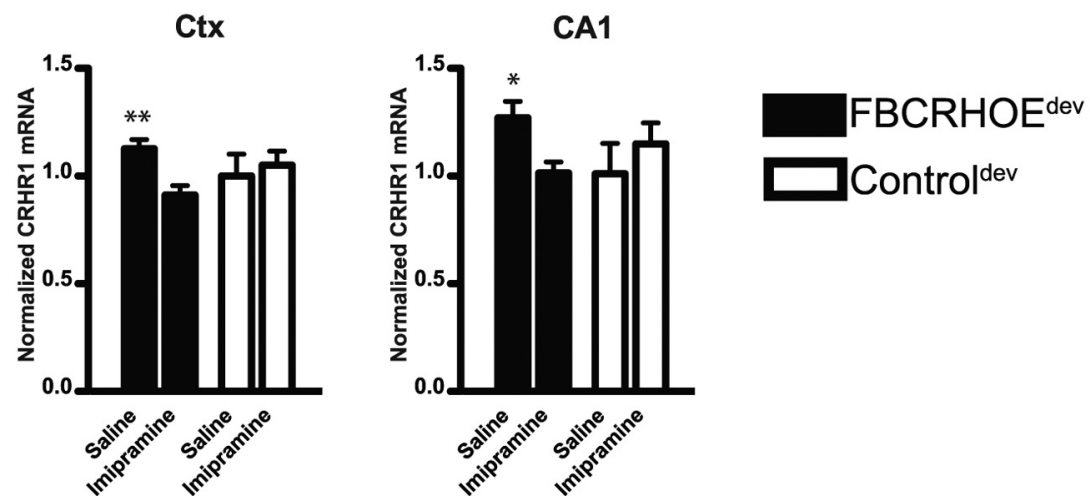

Figure 7. $F B C R H O E^{\text {dev }}$ mice show changes in CRHR1 mRNA expression that are reversed by imipramine treatment. $A$, Quantitation of GR mRNA from in situ hybridization of FBCRHOE ${ }^{\text {dev }}$ mice and control ${ }^{\text {dev }}$ mice in the PVN, CeA, BLA, DG, and CA1. $F B C R H O E^{\text {dev }}$ mice $(n=9)$ show equivalent GR expression compared with control ${ }^{\text {dev }}$ mice $(n=9)$. Right, Representative sections showing GR in situ signal. $\boldsymbol{B}$, Quantitation of basal CRHR1 mRNA in $F B C R H O E^{\mathrm{dev}}$ and control ${ }^{\mathrm{dev}}$ mice. $F B C R H O E^{\mathrm{dev}}$ mice $(n=3-9)$ show increased CRHR1 expression in the cingulate cortex (Ctx), DG and CA1 compared with control ${ }^{\text {dev }}$ mice $(n=4-9)$. On right, representative sections showing CRHR1 in situ signal in brain and pituitary gland (Pit). C, Chronic imipramine reduces CRHR1 expression in the $\mathrm{Ctx}$ and $C A 1$ in $F B C R H O E^{\mathrm{dev}}$ mice $\left(n=4\right.$ per treatment). No differences were observed between control ${ }^{\text {dev }}$ mice treated with saline $(n=4)$ or imipramine $(n=4)$ for either area. Student's $t$ test; ${ }^{*} p<0.05$; ${ }^{* *} p=0.01$ compared with control $^{\text {dev }}(\boldsymbol{B})$ or imipramine FBCRHOE $^{\text {dev }}(\boldsymbol{C})$.

long-term effects of early postnatal stress because this system allows us to look at stress-associated molecules without actually subjecting the mice to an external stressor. Although our temporal targeting from E15 to P21 of elevated $\mathrm{CRH}$ is an extension beyond the normal period for early-life stress studies in rodents, we believe that our ability to induce long-term behavioral changes in the absence of external stress makes our system a novel system to study the biochemical components of early-life stress. Importantly, in this study, we did not find any significant effects of doxycycline treatment on behavior in control mice. This sug- gests that differences observed between FBCRHOE ${ }^{\mathrm{dev}}$ mice and control ${ }^{\mathrm{dev}}$ are a result of the unique intersection of double transgenic genotype and time of overexpression. We find that transient early biochemical changes similar to those seen with early-life stress are likely to impact later behavioral and molecular sequelae. Of note, we do not know whether transient, but robust, elevation of $\mathrm{CRH}$ during adulthood would similarly lead to longterm behavioral sequelae.

The molecular changes we observed in $F B C R H O E^{\text {dev }}$ mice illustrate the dynamic nature of HPA axis-controlled molecules. First, we found no significant changes in GR mRNA in FBCRHOE ${ }^{\text {dev }}$ mice. This finding is interesting because early-life stress in rodents is associated with decreased GR expression, altered HPA axis activity and behavioral changes in adult animals (Aisa et al., 2008). Nonetheless, our results are consistent with the observation that during early-life stress disruption of forebrain CRHR1 does not influence GR mRNA expression despite increases in corticosterone in CRHR1 knockout (KO) mice (Schmidt et al., 2006). These and our data suggest that GR changes associated with maternal deprivation occur via a limbic CRH/CRHR1-independent pathway. In addition, we see normal HPA axis activity under circadian conditions and after restraint stress in adult FBCRHOE ${ }^{\mathrm{dev}}$ mice that cannot be accounted for by any observed changes in CRHR1 expression in the pituitary gland. These results suggest that the effects of early-life stress on behavior and HPA axis function can be dissociated. Specifically, our results with $F B C R H O E^{\text {dev }}$ mice suggest that early exposure to $\mathrm{CRH}$ in extrahypothalamic areas coupled with increased glucocorticoid levels during development are important factors in the long-term development of behavioral changes associated with depression and anxiety with reduced impact on adult HPA axis changes normally observed in a early-life stress models.

Our inducible system shows overexpression in the adult mouse in a variety of important limbic areas including the amygdala, hippocampus, and cortex. However, there exists the possibility that some of the endocrine and behavioral changes observed arose from ectopic expression of $\mathrm{CRH}$. Although the areas of highest endogenous CRH expression are the PVN and CeA, the other areas targeted in FBCRHOE mice do show the presence of endogenous CRH (Keegan et al., 1994) and CRHR (Aguilera et al., 2004), and/or respond to CRH activity under a variety of conditions (Brunson et al., 2001; Chen et al., 2001). Our observed increase in anxiety-like behavior is consistent with lowered anxiety-like behavior observed in forebrain restricted CRHR1 KO mice (Müller et al., 2003). 
Furthermore, our results do not provide the only confirmation of a forebrain-restricted role for the effects of early life stress on adult function. There is evidence that forebrain expressed serotonin $1 \mathrm{~A}$ receptor $(5-\mathrm{HT} 1 \mathrm{AR})$ can modulate long-term anxiety-like behavior (Gross et al., 2002). Using the tetracyclineoff system, researchers were able to show that expression of the 5-HT1AR in the forebrain (hippocampus, cortex, and amygdala) during early postnatal life is necessary and sufficient to rescue the anxiogenic behavior in conventional 5-HT1AR KO mice (Heisler et al., 1998; Parks et al., 1998; Gross et al., 2002).

Interestingly, we found reduced $\mathrm{CRH}$ expression in FBCRHOE $E^{\text {life }}$ mice in the PVN compared with endogenous levels in the control mice. It is likely that this reduction in $\mathrm{CRH}$ is an adaptive response to elevated glucocorticoids (Yi et al., 1993). The reason for the increase in FBCRHOE ${ }^{\text {life }}$ HPA axis activity despite a decrease in PVN CRH is unknown and could involve a number of factors. First, the levels of $\mathrm{CRH}$ overexpression in the FBCRHOE ${ }^{\text {life }}$ transgenic mice may be high enough that there is some leakage of CRH into the hypothalamic portal system. Another possibility may be related to the hypothesized role of CeA localized $\mathrm{CRH}$ in promoting HPA axis drive (Redgate and Fahringer, 1973) through induction of other peptides, such as vasopressin.

Notably, CRH overexpression in double transgenic mice was efficiently suppressed with doxycycline administration. Mice exposed to CRH from E15 to P21 show no changes in adult CRH expression in any area quantitated. Doxycycline suppression of transgenic overexpression is further supported by our finding that FBCRHOE mice on doxycycline from E0 to adulthood (i.e., $F B C R H O E^{\text {on doxy }}$ ) show no behavioral differences compared with control ${ }^{\text {dev }}$ mice. Furthermore, FBCRHOE ${ }^{\mathrm{dev}}$ mice show no significant changes in circadian HPA axis activity as adults. Changes in circadian corticosterone in FBCRHOE ${ }^{\mathrm{dev}}$ mice could have significantly hampered our ability to determine whether any changes in behavioral output are a result of long-term changes associated with early CRH exposure or merely continued HPA axis dysfunction.

Understanding the mechanisms of depression and anxiety can provide a novel framework to explore pharmacological treatment of these disorders. It has been hypothesized that CRH signaling through CRHR1 might be an important component of these mechanisms (Zobel et al., 2000). Between the two CRH receptors, CRHR1 is thought to contribute to increased behavioral disturbance (Claes, 2004). Disruption of CRHR1 throughout the mouse (Smith et al., 1998; Timpl et al., 1998) or restricted to the limbic forebrain (Müller et al., 2003) results in a decrease in anxiety-like behavior. As such, the increase in CRHR1 observed in FBCRHOE ${ }^{\text {dev }}$ mice may be involved in some of the behavioral changes that we observed especially considering the finding that our early $\mathrm{CRH}$ overexpression overlaps with the normal spatial and developmental pattern of CRHR1 expression (Vazquez et al., 2006). Interestingly, we found that imipramine treatment caused a decrease in CRHR1 mRNA expression in FBCRHOE ${ }^{\mathrm{dev}}$ mice in the cingulate cortex and area CA1. These data suggest that imipramine-induced CRHR1 expression changes may have played a role in the antidepressant reversal of the FBCRHOE ${ }^{\text {dev }}$ TST and FST despair-like phenotype. Supporting this link between CRHR1 and despair-like behavior, recent evidence has suggested that polymorphisms in CRHR1 may be related to the effect of early-life stress on human adult depression (Bradley et al., 2008).

It is likely that our similar results using acute versus chronic imipramine reflect a common mechanism between treatment schedules. We do, in general, find a stronger effect of antidepres- sant treatment in the FBCRHOE ${ }^{\text {dev }}$ mice compared with the control $^{\text {dev }}$ mice, suggesting a specific antidepressant effect rather than a nonspecific change in locomotion. Of note, we found a difference between chronic and acute imipramine treatment in the FST. Although both treatment schedules increased activity of $F B C R H O E^{\mathrm{dev}}$ mice, in the acute test, imipramine also increased activity in the control ${ }^{\text {dev }}$ mice compared with saline-treated control $^{\text {dev }}$ mice. These data are consistent with previous research showing different effects of chronic and acute treatment in the FST (Detke et al., 1997; Boyle et al., 2005).

In contrast to the effects of chronic imipramine on the TST and FST, we were unable to show a reversal of the anxiety-like phenotype of FBCRHOE ${ }^{\mathrm{dev}}$ mice in open-field behavior with antidepressant treatment. However, daily handling associated with vehicle treatment seemed to increase anxiety in control ${ }^{\mathrm{dev}}$ mice to the point that for all measures except for the number of center zone entries, no differences were detected between saline-treated FBCRHOE ${ }^{\mathrm{dev}}$ mice and saline-treated control ${ }^{\mathrm{dev}}$ mice.

The observed long-lasting effects of early CRH exposure may be related to the role of CRH in hippocampal differentiation (Yan et al., 1998). Research in CRHR1 KO mice has suggested that early effects of increased CRH might induce long-term changes in neuronal connectivity (Chen et al., 2004b). Specifically, CRHR1 KO mice exhibit increased growth of dendritic processes during the early postnatal period. We found an increase in basal CRHR1 mRNA expression in the hippocampus and cortex in adult animals exposed to $\mathrm{CRH}$ early in life. Future research looking at hippocampal growth in $F B C R H O E^{\mathrm{dev}}$ juvenile and adult mice should be informative in determining what role changes in hippocampal growth may play in any memory-related changes in these mice.

In humans, a variety of early stressors including physical abuse, sexual abuse, and parental loss have a significant impact on the development of adult endocrine and behavioral changes (Nemeroff, 2004). Our results suggest that some of the effects of stress in humans may be mediated by CRH activity in forebrain areas. Overall, we have demonstrated that increased CRH expression in the forebrain of mice induces an increase in anxiety-like and despair-like behavioral changes. These effects of CRH appear to be set early in development as animals exposed to $\mathrm{CRH}$ before weaning maintain behavioral changes as adults. The behavioral effects are associated with long-term changes in CRHR1 mRNA expression and can be reversed with imipramine. These results have important implications for understanding the role of the neuroendocrine system in MDD. The observation that early exposure to $\mathrm{CRH}$ in the forebrain causes long-term behavioral changes suggests that researchers and clinicians should explore the use of pharmacological blockade of $\mathrm{CRH}$ receptors in a prophylactic manner before high-risk patients develop psychiatric illness. The FBCRHOE ${ }^{\text {dev }}$ mice should provide a useful model to begin testing this scenario.

\section{References}

Aguilera G, Nikodemova M, Wynn PC, Catt KJ (2004) Corticotropin releasing hormone receptors: two decades later. Peptides 25:319-329.

Aisa B, Tordera R, Lasheras B, Del Río J, Ramírez MJ (2008) Effects of maternal separation on hypothalamic-pituitary-adrenal responses, cognition and vulnerability to stress in adult female rats. Neuroscience 154:1218-1226.

Arató M, Bánki CM, Bissette G, Nemeroff CB (1989) Elevated CSF CRF in suicide victims. Biol Psychiatry 25:355-359.

Boyle MP, Brewer JA, Funatsu M, Wozniak DF, Tsien JZ, Izumi Y, Muglia LJ (2005) Acquired deficit of forebrain glucocorticoid receptor produces depression-like changes in adrenal axis regulation and behavior. Proc Natl Acad Sci U S A 102:473-478.

Boyle MP, Kolber BJ, Vogt SK, Wozniak DF, Muglia LJ (2006) Forebrain 
glucocorticoid receptors modulate anxiety-associated locomotor activation and adrenal responsiveness. J Neurosci 26:1971-1978.

Bradley RG, Binder EB, Epstein MP, Tang Y, Nair HP, Liu W, Gillespie CF, Berg T, Evces M, Newport DJ, Stowe ZN, Heim CM, Nemeroff CB, Schwartz A, Cubells JF, Ressler KJ (2008) Influence of child abuse on adult depression: moderation by the corticotropin-releasing hormone receptor gene. Arch Gen Psychiatry 65:190-200.

Brunson KL, Eghbal-Ahmadi M, Bender R, Chen Y, Baram TZ (2001) Longterm, progressive hippocampal cell loss and dysfunction induced by early-life administration of corticotropin-releasing hormone reproduce the effects of early-life stress. Proc Natl Acad Sci U S A 98:8856-8861.

Burgin KE, Waxham MN, Rickling S, Westgate SA, Mobley WC, Kelly PT (1990) In situ hybridization histochemistry of $\mathrm{Ca}^{2+} /$ calmodulin-dependent protein kinase in developing rat brain. J Neurosci 10:1788-1798.

Chen Y, Bender RA, Frotscher M, Baram TZ (2001) Novel and transient populations of corticotropin-releasing hormone-expressing neurons in developing hippocampus suggest unique functional roles: a quantitative spatiotemporal analysis. J Neurosci 21:7171-7181.

Chen Y, Brunson KL, Adelmann G, Bender RA, Frotscher M, Baram TZ (2004a) Hippocampal corticotropin releasing hormone: pre- and postsynaptic location and release by stress. Neuroscience 126:533-540.

Chen Y, Bender RA, Brunson KL, Pomper JK, Grigoriadis DE, Wurst W, Baram TZ (2004b) Modulation of dendritic differentiation by corticotropinreleasing factor in the developing hippocampus. Proc Natl Acad Sci U S A 101:15782-15787.

Claes SJ (2004) CRH, stress, and major depression: a psychobiological interplay. Vitam Horm 69:117-150.

De Bellis MD, Chrousos GP, Dorn LD, Burke L, Helmers K, Kling MA, Trickett PK, Putnam FW (1994) Hypothalamic-pituitary-adrenal axis dysregulation in sexually abused girls. J Clin Endocrinol Metab 78:249-255.

Detke MJ, Johnson J, Lucki I (1997) Acute and chronic antidepressant drug treatment in the rat forced swimming test model of depression. Exp Clin Psychopharmacol 5:107-112.

Gross C, Zhuang X, Stark K, Ramboz S, Oosting R, Kirby L, Santarelli L, Beck S, Hen R (2002) Serotoni1A receptor acts during development to establish normal anxiety-like behaviour in the adult. Nature 416:396-400.

Hatalski CG, Guirguis C, Baram TZ (1998) Corticotropin releasing factor mRNA expression in the hypothalamic paraventricular nucleus and the central nucleus of the amygdala is modulated by repeated acute stress in the immature rat. J Neuroendocrinol 10:663-669.

Hatalski CG, Brunson KL, Tantayanubutr B, Chen Y, Baram TZ (2000) Neuronal activity and stress differentially regulate hippocampal and hypothalamic corticotropin-releasing hormone expression in the immature rat. Neuroscience 101:571-580.

Heim C, Newport DJ, Heit S, Graham YP, Wilcox M, Bonsall R, Miller AH, Nemeroff CB (2000) Pituitary-adrenal and autonomic responses to stress in women after sexual and physical abuse in childhood. JAMA 284:592-597.

Heim C, Mletzko T, Purselle D, Musselman DL, Nemeroff CB (2008) The dexamethasone/corticotropin-releasing factor test in men with major depression: role of childhood trauma. Biol Psychiatry 63:398-405.

Heisler LK, Chu HM, Brennan TJ, Danao JA, Bajwa P, Parsons LH, Tecott LH (1998) Elevated anxiety and antidepressant-like responses in serotonin 5-HT1A receptor mutant mice. Proc Natl Acad Sci U S A 95:15049-15054.

Ho N, Liauw JA, Blaeser F, Wei F, Hanissian S, Muglia LM, Wozniak DF, Nardi A, Arvin KL, Holtzman DM, Linden DJ, Zhuo M, Muglia LJ, Chatila TA (2000) Impaired synaptic plasticity and cAMP response element-binding protein activation in $\mathrm{Ca}^{2+} /$ calmodulin-dependent protein kinase type IV/Gr-deficient mice. J Neurosci 20:6459-6472.

Holson RR, Scallet AC, Ali SF, Turner BB (1991) “Isolation stress" revisited: isolation-rearing effects depend on animal care methods. Physiol Behav 49:1107-1118.

Keegan CE, Herman JP, Karolyi IJ, O'Shea KS, Camper SA, Seasholtz AF (1994) Differential expression of corticotropin-releasing hormone in developing mouse embryos and adult brain. Endocrinology 134:2547-2555.

Lemieux AM, Coe CL (1995) Abuse-related posttraumatic stress disorder: evidence for chronic neuroendocrine activation in women. Psychosom Med 57:105-115.

Lu A, Steiner MA, Whittle N, Vogl AM, Walser SM, Ableitner M, Refojo D, Ekker M, Rubenstein JL, Stalla GK, Singewald N, Holsboer F, Wotjak CT, Wurst W, Deussing JM (2008) Conditional mouse mutants highlight mechanisms of corticotropin-releasing hormone effects on stress-coping behavior. Mol Psychiatry 13:1028-1042

Marco EM, Adriani W, Llorente R, Laviola G, Viveros MP (2008) Detrimental psychophysiological effects of early maternal deprivation in adolescent and adult rodents: altered responses to cannabinoid exposure. Neurosci Biobehav Rev 33:498-507

Mayford M, Bach ME, Huang YY, Wang L, Hawkins RD, Kandel ER (1996) Control of memory formation through regulated expression of a CaMKII transgene. Science 274:1678-1683.

Misslin R, Herzog F, Koch B, Ropartz P (1982) Effects of isolation, handling and novelty on the pituitary-adrenal response in the mouse. Psychoneuroendocrinology 7:217-221.

Muglia L, Jacobson L, Dikkes P, Majzoub JA (1995) Corticotropin-releasing hormone deficiency reveals major fetal but not adult glucocorticoid need. Nature 373:427-432.

Müller MB, Zimmermann S, Sillaber I, Hagemeyer TP, Deussing JM, Timpl P, Kormann MS, Droste SK, Kühn R, Reul JM, Holsboer F, Wurst W (2003) Limbic corticotropin-releasing hormone receptor 1 mediates anxiety-related behavior and hormonal adaptation to stress. Nat Neurosci 6:1100-1107.

Nemeroff CB (2004) Neurobiological consequences of childhood trauma. J Clin Psychiatry 65 [Suppl 1]:18-28.

Parks CL, Robinson PS, Sibille E, Shenk T, Toth M (1998) Increased anxiety of mice lacking the serotonin1A receptor. Proc Natl Acad Sci U S A 95:10734-10739.

Redgate ES, Fahringer EE (1973) A comparison of the pituitary adrenal activity elicited by electrical stimulation of preoptic, amygdaloid and hypothalamic sites in the rat brain. Neuroendocrinology 12:334-343.

Roozendaal B, Brunson KL, Holloway BL, McGaugh JL, Baram TZ (2002) Involvement of stress-released corticotropin-releasing hormone in the basolateral amygdala in regulating memory consolidation. Proc Natl Acad Sci U S A 99:13908-13913.

Schmidt MV, Deussing JM, Oitzl MS, Ohl F, Levine S, Wurst W, Holsboer F, Müller MB, de Kloet ER (2006) Differential disinhibition of the neonatal hypothalamic- pituitary-adrenal axis in brain-specific CRH receptor 1-knockout mice. Eur J Neurosci 24:2291-2298.

Smith GW, Aubry JM, Dellu F, Contarino A, Bilezikjian LM, Gold LH, Chen R, Marchuk Y, Hauser C, Bentley CA, Sawchenko PE, Koob GF, Vale W, Lee KF (1998) Corticotropin releasing factor receptor 1-deficient mice display decreased anxiety, impaired stress response, and aberrant neuroendocrine development. Neuron 20:1093-1102.

Stenzel-Poore MP, Cameron VA, Vaughan J, Sawchenko PE, Vale W (1992) Development of Cushing's syndrome in corticotropin-releasing factor transgenic mice. Endocrinology 130:3378-3386.

Stenzel-Poore MP, Heinrichs SC, Rivest S, Koob GF, Vale WW (1994) Overproduction of corticotropin-releasing factor in transgenic mice: a genetic model of anxiogenic behavior. J Neurosci 14:2579-2584.

Timpl P, Spanagel R, Sillaber I, Kresse A, Reul JM, Stalla GK, Blanquet V, Steckler T, Holsboer F, Wurst W (1998) Impaired stress response and reduced anxiety in mice lacking a functional corticotropin-releasing hormone receptor 1. Nat Genet 19:162-166.

Vazquez DM, Bailey C, Dent GW, Okimoto DK, Steffek A, López JF, Levine S (2006) Brain corticotropin-releasing hormone (CRH) circuits in the developing rat: effect of maternal deprivation. Brain Res 1121:83-94.

Wei Q, Lu XY, Liu L, Schafer G, Shieh KR, Burke S, Robinson TE, Watson SJ, Seasholtz AF, Akil H (2004) Glucocorticoid receptor overexpression in forebrain: a mouse model of increased emotional lability. Proc Natl Acad Sci U S A 101:11851-11856.

Yan XX, Toth Z, Schultz L, Ribak CE, Baram TZ (1998) Corticotropinreleasing hormone $(\mathrm{CRH})$-containing neurons in the immature rat hippocampal formation: light and electron microscopic features and colocalization with glutamate decarboxylase and parvalbumin. Hippocampus 8:231-243.

Yi SJ, Masters JN, Baram TZ (1993) Effects of a specific glucocorticoid receptor antagonist on corticotropin releasing hormone gene expression in the paraventricular nucleus of the neonatal rat. Brain Res Dev Brain Res 73:253-259.

Zobel AW, Nickel T, Künzel HE, Ackl N, Sonntag A, Ising M, Holsboer F (2000) Effects of the high-affinity corticotropin-releasing hormone receptor 1 antagonist R121919 in major depression: the first 20 patients treated. J Psychiatr Res 34:171-181. 